https://www.journal-imab-bg.org

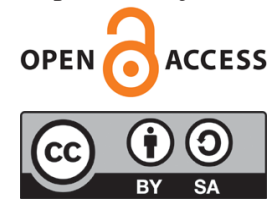

Original article

\title{
SERUM LEVELS OF ADENOSINE DEAMINASE IN PATIENTS WITH TUBERCULOSIS AND INFLAMMATORY LUNG DISEASE
}

\author{
Irena I. Gencheva \\ Department of Clinical Laboratory, Clinical Immunology and Allergology, \\ Medical University - Pleven, Bulgaria..
}

\section{SUMMARY}

Introduction: Serum adenosine deaminase (ADA) levels are used to diagnose tuberculosis and to monitor the condition of the patients during hospital treatment.

Purpose: The aim of the present study is to establish the diagnostic value of serum ADA in patients with inflammatory lung disease, including pulmonary tuberculosis.

Materials and methods: We measured ADA levels in 66 patients with lung disease, of whom 33 were men and 33 were women, all aged 18 to 86 years. Among the patients studied, 12 were diagnosed with tuberculosis, 34 with bacterial pneumonia and 20 with pleural effusion.

Results: We found that the serum ADA levels in our patients were higher than $18 \mathrm{U} / 1$, which are the recommended upper limit in healthy people, according to the test performed by our laboratory. ADA levels were also higher than $21 \mathrm{U} / 1$, the value we defined as the mean in healthy individuals in our previous study.

Conclusion: Based on our study, we can say that serum ADA levels in the patients we have studied with lung diseases, including pulmonary tuberculosis, have a high diagnostic value.

Keywords: ADA, diagnosis, tuberculosis,

\section{INTRODUCTION}

Tuberculosis is one of the leading causes of death and morbidity worldwide. According to WHO, in 2018, the number of people globally suffering from tuberculosis is over 10 million, 1.5 million of whom died, and 484 thousand have developed resistant forms of the disease.

Various diagnostic methods are used to diagnose tuberculosis - microbiological detection of Mycobacterium tuberculosis and culture in Lowenstein-Jensen medium are the 'gold standards'. In the widely used Mantoux test after 72 hours, pass values above $15 \mathrm{~mm}$ are considered hyperergic. Isolating tuberculosis bacteria from sputum is the main and most trustworthy method. However, its disadvantage is the need for a significant number of bacteria in the test material. Another method used is the polymerase chain reaction (PCR). It is expensive, requires qualified staff and a lot of equipment. Many laboratories also use a relatively new automated diagnostic test that can identify Mycobac- terium tuberculosis DNA and rifampicin resistance. There are also screening methods for detecting acid-fast bacilli, but their sensitivity is low. Therefore, there is a great demand recently for new microbiological, genetic, immunological and biomedical diagnostic methods for a rapid and accurate diagnosis of tuberculosis. Advances in immunological research have led to the introduction of new, significantly more sensitive methods than.

Measurement of the adenosine deaminase (ADA) activity is a biomedical method. ADA is essential for the proliferation and differentiation of lymphoid cells, especially $\mathrm{T}$ cells, and helps the maturation of monocytes to macrophages. The activity of this enzyme is increased in patients with tuberculosis. The level of ADA in sputum and serum is used to diagnose tuberculosis and is observed during the treatment of tuberculosis [1, 2, 3]. Enzyme testing is mainly used for pleural effusion, where microbiological testing often gives a negative result. Pleural ADA values above $20 \mathrm{U} / 1$ in combination with lymphocytic effusion are considered a positive result. However, testing for pleural effusion is not always possible, so it would be useful to take advantage of serum enzyme levels $[4,5,6,7]$.

Elevated ADA levels have been reported not only in tuberculosis and tuberculosis pleural effusionbut also in some other inflammatory lung diseases, pulmonary fibrosis and cancer as adenosine levels are increased in cell damage, cell stress and hypoxia [8].

\section{PURPOSE}

The aim of this study is to evaluate the diagnostic value of serum ADA levels in patients with inflammatory lung disease, including pulmonary tuberculosis.

\section{PATIENTS AND METHODS}

In our study, we examined patients from the University Hospital "DrGeorgiStranski" Pleven with lung disease, who all have signed an informed consent during their admission. The studied patients were 66 aged 18 to 86 years, of which 33 men and 33 women. The average age for men is 54 years (18-86 years) and for women 49 years (22-77 years). Of the patients studied, 12 were diagnosed with tuberculosis, 34 had bacterial pneumonia, and 20 had pleural effusion in connection to other pulmonary diseases.

As a control group, we used the results of our previ- 
ous study, where we examined 160 healthy individuals aged 18 to 84 years, of whom 64 were men and 96 were women. Serum adenosine deaminase levels were determined by a method based on the enzyme's ability to catalyze the deamination of adenosine to inosine and ammonia. The catalytic concentration was determined spectrophotometrically by the NADH reduction rate measured at $340 \mathrm{~nm}$.

\section{RESULTS}

As expected, we found out that the serum ADA values in the studied patients were not in the recommended reference range for the method we used, namely below $18 \mathrm{U}$ / 1. The reference values of serum ADA that we developed in our control group were higher than $18 \mathrm{U} / \mathrm{l}$ even in healthy people, namely; for women, we found a reference range from
14.5 U / 1 to $25.7 \mathrm{U} / 1$, and for men from $18.5 \mathrm{U} / \mathrm{l}$ to $27.5 \mathrm{U}$ $/ 1$, as the average value for both sexes is very close - for women 21.07 U / 1, and for men 21.30U / 1. [9]

In the present research, we found that the mean serum ADA levels in patients with tuberculosis were $28.14 \mathrm{U}$ / 1 , in patients with pneumonia were $30.64 \mathrm{U} / 1$, and in patients with pleural effusion were $37.59 \mathrm{U} / 1$. In all groups, serum ADA levels were higher than $21 \mathrm{U} / 1$, the value we determined as the median for healthy people. (Fig. 1). We found that the mean values of $\mathrm{ADA}$ in the serum of men and women with tuberculosis and pneumonia are very similar, and this can be seen in Table 1 . In patients with pleural effusion, however, the differences in the values of ADA are greater, respectively in men 45,57 U / 1, and in women $29,62 \mathrm{U} / 1$.

Fig. 1. Meanserum ADA levels in patients with TB, Pneumonia and Pleural effusion

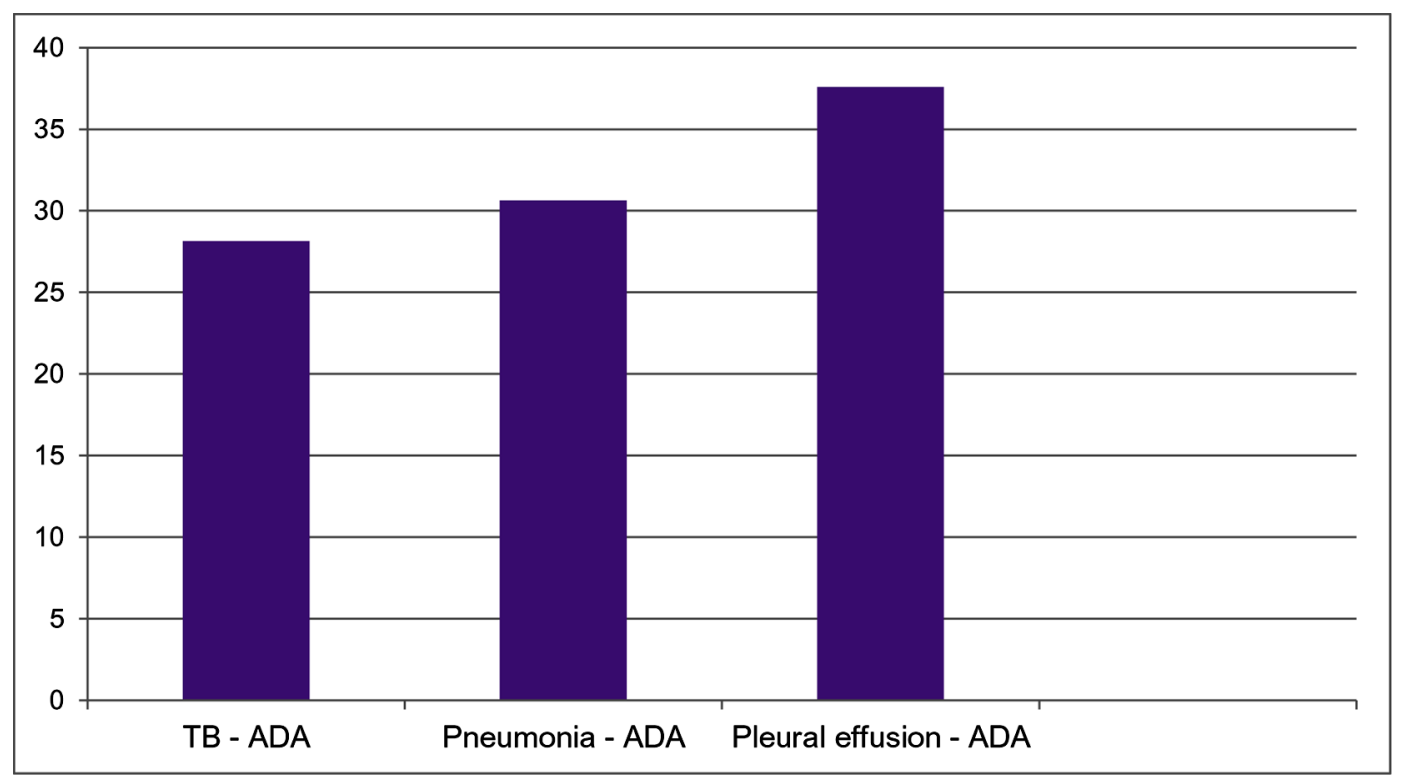

Tabl. 1. ADA serum levels according to sex and type of lung disease

\begin{tabular}{|c|c|c|c|c|c|}
\hline & Number & Age & TB - & $\begin{array}{c}\text { Pneumonia }- \\
\text { ADA }\end{array}$ & $\begin{array}{c}\text { Pleural effusion }- \\
\text { ADA }\end{array}$ \\
\hline Women & 33 & $\begin{array}{c}\overline{\mathrm{x}}=49 \\
(22-77)\end{array}$ & $\mathrm{x}=28 \mathrm{U} / \mathrm{L}$ & $\mathrm{x}=30.14 \mathrm{U} / \mathrm{L}$ & $\mathrm{x}=45.57 \mathrm{U} / \mathrm{L}$ \\
\hline Men & 33 & $\begin{array}{c}\overline{\mathrm{x}}=54 \\
(18-86)\end{array}$ & $\mathrm{x}=28.25 \mathrm{U} / \mathrm{L}$ & $\mathrm{x}=31 \mathrm{U} / \mathrm{L}$ & $\mathrm{x}=29.62 \mathrm{U} / \mathrm{L}$ \\
\hline Sum & 66 & $18-86$ & $\overline{\mathrm{x}}=28,14 \mathrm{U} / \mathrm{L}$ & $\overline{\mathrm{x}}=30,64 \mathrm{U} / \mathrm{l}$ & $\overline{\mathrm{x}}=37,59 \mathrm{U} / 1$ \\
\hline
\end{tabular}

\section{DISCUSSION}

Serum ADA levels are the highest in the group of patients with pleural effusion, where we can also find the largest variations in values from $10 \mathrm{U} / 1$ to $116 \mathrm{U} / 1$.In addition, this group has the largest differences in values between the two sexes. It is noteworthy that in patients with pulmonary tuberculosis, the average value is not much higher than our established upper reference limit in women - 25,7 U/1 and in men - 27,5 U/1. We found that in men with tuberculosis, the average value for ADA is
28, 25U/1 and in women - 28 U/l. Different studies cite different ADA cut-off values at which sensitivity, specificity and positive prognostic value are very high. Such differences may be due to the severity of tuberculosis, age, genetic differences, and differences in control groups. Therefore, studies to determine normal ADA levels in different societies are very useful. [10, 11,12]. In connection to this, an increased number of patients compared to that in our study would be more significant. 


\section{CONCLUSION}

According to our research, the level of ADA in serum has a high diagnostic value in patients with inflammatory lung disease and pulmonary tuberculosis. Above the value of $21 \mathrm{U} / \mathrm{L}$, the prognostic value of ADA is considered high.

\section{REFERENCES:}

1. Alaarag AH, Mohammad OI, Faraq NM.Diagnostic utility of serum adenosine deaminase level in the diagnosis of pulmonary tuberculosis. Egypt J Bronchol. 2016; 10(2):133-9. [Crossref]

2. Navari K, Eftekhaari TE, Ziaee N, Navari F. Decreasing level of serum ADA: A valuable predictor of treatment in smear positive tuberculosis. European Respiratory Journal. 2011; 38(Suppl 55):p4382.

3. Boloursaz M, Khalilzadeh S, Khodayari A, Hakimi S. Adenosine Deaminase Level as an Indicator for Differentiating Between Active Pulmonary Tuberculosis Infection and Other Pulmonary Infections. Compr Ped. 2012; 3(1):3-6. [Crossref]

4. Farazi A, Moharamkhani A, Sofian M. Validity of serum adenosine deaminase in diagnosis of tuberculosis. Pan Afr Med J. 2013 Aug 14; 15:133. [PubMed] [Crossref]

5. Jhamaria JP, Jenaw RK, Luh SK,
Mathur DK, Parihar HL, Sharma SK. Serum adenosine deaminase (ADA) in differential diagnosis of pulmonary tuberculosis and common non tubercular respiratory diseases. Ind $J T u b$. 1988; 35:25-27.

6. Varma S, Toppo A. Estimation of Serum Adenosine Deaminase Levelin Patients of Pulmonary Tuberculosisin a Tertiary Care Hospital in Chhattisgarh. Int J Res Health Sci. 2015 OctDec;3(4): 451-456. [Internet]

7. Afrasiabian S, Mohsenpour B, Bagheri KH, Sigari N, Aftabi K. Diagnostic value of serum adenosine deaminase level in pulmonary tuberculosis. J Res Med Sci. 2013 Mar; 18(3):252-4. [PubMed]

8. Farahmand F, Tajdini P, Falahi G, Shams S, Mahmoudi S. Evaluation of Serum Adenosine Deaminase in Cystic Fibrosis Patients in an Iranian Referral Hospital. Iran J Pediatr. $2016 \mathrm{Feb}$ 10;26(3):e2246. [PubMed] [Crossref]

9. Gencheva II, Angelova IA,
Ruseva AL. Serum Adenosine Deaminase Values In Healthy People. J B Bio Engine. 2020 Jun;1(1):2. [Crossref]

10. Conde MB, Marinho SR, de Fatima Pereira M, Lapa e Silva JR, Saad MHF, Sales CL, et al. The usefulness of serum adenosine deaminase 2 (ADA2) activity in adults for the diagnosis of pulmonary tuberculosis. Respir Med. 2002 Aug;96(8):607-10. [PubMed] [Crossref]

11. Gupta BK, Bharat V, Bandyopadhyay D. Sensitivity, specificity, negative and positive predictive values of adenosine deaminase in patients of tubercular and non-tubercular serosal effusion in India. J Clin Med Res. 2010 May 19;2(3):121-6. [PubMed] [Crossref]

12. Aggarwal AN, Agarwal R, Sehgal IS, Dhooria S. Adenosine deaminase for diagnosis of tuberculous pleural effusion: A systematic review and metaanalysis. PLoS One. 2019 Mar 26; 14(3):e0213728. [PubMed] [Crossref]

Please cite this article as: Gencheva II. Serum levels of adenosine deaminase in patients with tuberculosis and inflammatory lung disease. $J$ of IMAB. 2020 Oct-Dec;26(4):3449-3451. DOI: https://doi.org/10.5272/jimab.2020264.3449

Received: 19/10/2019; Published online: 19/11/2020

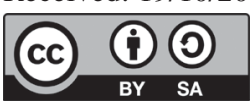

Address for correspondence:

Irena I. Gencheva

Department of Clinical laboratory, Clinical immunology and alergology, Medical University - Pleven

E-mail: gencheva1677@gmail.com 